\title{
Średniowieczne znaki pielgrzymie z Einsiedeln w zbiorach Muzeum Archeologicznego w Gdańsku
}

\author{
Medieval pilgrim souvenirs from Einsiedeln in the collection \\ of the Gdańsk Archaeological Museum
}

W zbiorach Muzeum Archeologicznego w Gdańsku znajduje się dziewięć pamiątek pielgrzymich pochodzących z Einsiedeln w Szwajcarii, przy czym wszystkie to znaki pielgrzymie wykonane metodą odlewu z cyno-ołowiu. Zostały one odkryte w trakcie ratowniczych badań wykopaliskowych prowadzonych systematycznie na terenie Gdańska od roku 1988 (Paner 1993a, s. 155-188; 1993b, s. 53-56; 1993c, s. 125-131; 1997a, s. 277-291; 1997b, s. 7-35; 2009, s. 11-88; Paner A., Paner H., 1998, s. 167-183). Dwa z nich pochodzą z Wyspy Spichrzów, jeden z dzielnicy Długie Ogrody, dwa z Lastadii - na Starym Przedmieściu, trzy ze Starego Miasta oraz jeden z Głównego Miasta.

Pierwszy przedmiot z Wyspy Spichrzów (GKPP 81; nr SAZ²: 255/020/039; nr katalogu: 5362; ryc. 1) znaleziono przy ulicy Motławskiej 1, w obrębie podwórka funkcjonującego na tej parceli przed budową pierwszego spichlerza, który

\footnotetext{
${ }^{1}$ GKPP - Gdańska Kolekcja Pamiątek Pielgrzymich utworzona przez autora niniejszego artykułu.

${ }^{2}$ Identyfikatorem omawianych zabytków jest numer na liście Gdańskiej Kolekcji Pamiątek Pielgrzymich. Lista została utworzona po to, aby w odrębnej bazie danych rejestrować wszelkie informacje o znaleziskach z terenu Gdańska, związanych ze średniowiecznymi pielgrzymkami Ich numery zostały nierozerwalnie połączone w bazie danych z elektronicznym Systemem Ewidencji Zabytków (SAZ), zaimplementowanym w Muzeum Archeologicznym w Gdańsku (MAG), który daje możliwość ustalenia relacji zachodzących między zabytkiem a jego kontekstem. Numer SAZ składa się z trzech części (np. 255/020/039). Pierwsza oznacza numer teki archiwalnej (np. 255), co pozwala systemowi zidentyfikować miejscowość, z której pochodzi znalezisko, druga - numer stanowiska archeologicznego (np. 002), trzecia odnosi się do pozyskania (np. 008), czyli jest to numer kolejnej akcji badawczej prowadzonej na tym właśnie stanowisku. Tak więc numer SAZ pozwala w elektronicznej bazie danych o nazwie „Fibula” jednoznacznie odnaleźć i zidentyfikować nie tylko stanowisko i sezon badawczy, ale także instytucję prowadzącą, kierownika badań, zarejestrowane konteksty i zabytki etc. Do niego dowiązane są numery katalogowe zabytków $\mathrm{z}$ danego stanowiska, oznaczone w ramach poszczególnych akcji badawczych (pozyskań), w ciągu - od 1 do ... n.
} 
wybudowany został dopiero u schyłku średniowiecza lub w początkach okresu nowożytnego ${ }^{3}$, co wyznacza terminus post quem dla omawianego znaleziska. Zachowany w około $50 \%$ ażurowy znak pielgrzymi ma wymiary $37 \times 51 \mathrm{~mm}^{4}$. Przedstawia ustawioną frontalnie Marię w sukni i maforium, w koronie na głowie otoczonej nimbem. Postać zasiada na tronie usytuowanym wewnątrz kapliczki, ze stojącym na jej kolanach nagim Dzieciątkiem, opierającym się o jej lewe ramię. Obok, za ościeżem (drzwi?), tyłem do Marii stoi anioł. Dookoła plakietki znajduje się płaska ramka z minuskułowym, gotyckim napisem, który w zachowanej części odczy tano jako: neisidelen*die*wirkt*got ${ }^{*}$ sel...*. Z czterech uszek do mocowania dwa są zachowane 5 .

Druga plakietka z Wyspy Spichrzów (GKPP 236; nr SAZ: 255/020/039; nr katalogu: 5385; ryc. 2), pochodzi z badań prowadzonych przy ulicy Basztowej 3, z kontekstu związanego z kolejną fazą rozbudowy istniejącego tu drewnianego spichlerza ${ }^{6}$. Zachował się tylko niewielki fragment ażurowego znaku o wymiarach $59 \times 57 \mathrm{~mm}$, stanowiący część frontu kapliczki oraz jego zwieńczenia $\mathrm{w}$ formie trójkątnej banderoli $\mathrm{z}$ napisem wykonanym minuskułą gotycką, z bardzo czytelnymi literami, który w zachowanej części odczytano jako: selb*mit*engel*dis*ist*vn...*7.

Kolejne znalezisko pochodzi z dzielnicy Długie Ogrody (GKPP 322; nr SAZ: 255/100/005; nr katalogu: 5010; ryc. 3); został wyeksplorowany przy ulicy Szafarnia 12-14 z nawarstwień uznanych za niwelacyjne, powstałe w trakcie systematycznego, intencjonalnego podnoszenia powierzchni terenu lub zasypywania podmokłych zagłębień. Podobnie jak w przypadku pierwszego opisywanego zabytku, jest to fragment ażurowej plakietki o wymiarach $31 \times 53 \mathrm{~mm}$, z postacią Madonny oraz ze stojącym na jej kolanach nagim Dzieciątkiem; oboje umieszczeni są pod daszkiem niewielkiej kaplicy. Dookoła znaku biegnie płaska ramka z minuskułowym napisem gotyckim, odczytanym jako: ...(n ?) siedelen $*$ die ${ }^{*}$ wirht $^{*}{ }_{\text {got }}{ }^{*}$ selb $^{*}$ mit $^{8}$.

${ }^{3}$ Warstwa 1644, VII horyzont osadniczy. Spichlerz wzniesiono w XIV fazie zabudowy. Badania były prowadzone latach 2000-2001 przez Zbigniewa Borcowskiego.

${ }^{4}$ Wymiary zabytków są podawane w kolejności: szerokość, wysokość.

${ }_{5}^{5}$ Jedna z lepiej zachowanych plakietek, o wymiarach $63 \times 76 \mathrm{~mm}$, znana jest z Nieuwlande w Holandii i datowana na lata 1400-1500. Z tego samego okresu pochodzi plakietka o wymiarach $68 \times 77$ mm, znaleziona w Szwecji, w miejscowości Gamla-Lödöse. Doskonale zachowany znak ze Sneek w Holandii, o wymiarach $73 \times 68$ mm, także jest datowany na lata 1400-1500 (Spencer 1968, s. 139; Heeringen, Koldeweij, Gaalman 1987, s. 119-120; Andersson 1989; Böck 1991, s. 52; nr 42.1; Beuningen, Koldeweij 1993, s. 218, ryc. 446; Lustenberger 2000, s. 266; Beuningen, Koldeweij, Kicken 2001, s. 334, nr 1393).

${ }^{6}$ Warstwa 1039, faza 6, VI horyzont osadniczy. Badania były prowadzone w latach 2000-2001 przez Zbigniewa Borcowskiego.

${ }^{7}$ Podobna plakietka pochodzi z wyżej wymieniongo Gamla-Lödöse w Szwecji i jest datowana na lata 1400-1499. Całą treść zachowanego na niej napisu odczytano jako: dis ist unser lieben frauen capelle zeichen von einsiedelen die wiett gott selbst mit engeln (Andersson 1989, s. 89, nr 1).

${ }^{8}$ Podobna plakietka znana jest ze Sneek w Holandii; przedstawia Marię z Jezusem znajdujących się pod dachem niewielkiej kaplicy, w której drzwiach stoi anioł, tyłem do nich, zaś przodem do 
Zachowały się dwa z czterech uszek do mocowania. Wspomniane nawarstwienia niwelacyjne zawierały liczne monety datowane od schyłku XIV do XVII stulecia, z czego dwie na XIV wiek, 22 na XV wiek, 6 na XVI wiek oraz dwie na XVII wiek, jednakże te ostatnie zostały znalezione na wtórnym złożu (Paszkiewicz w druku).

Dwie kolejne plakietki pochodzą z rejonu Lastadii, usytuowanej na południowych obrzeżach Głównego Miasta, już poza jego średniowiecznymi murami. Teren ten położony jest przy zachodnim nabrzeżu Starej Motławy, w obrębie funkcjonowania średniowiecznego portu gdańskiego oraz miejsca budowy i remontu statków. Jedną plakietkę (GKPP 385; nr SAZ: 255/133/003; nr katalogu: 4205; ryc. 4) znaleziono w rejonie pobrzeża portowego ${ }^{9}$, w kontekście datowanym na XV wiek. Podobnie jak uprzednio prezentowane, jest ona ażurowa, lecz tym razem zachowana w większej części, ma wymiary 68,7 × 69,6 mm. Plakietka przedstawia postać Madonny z Dzieciątkiem na rękach, umieszczoną pod dachem kapliczki. Obok, po lewej stronie (heraldycznie) znajdują się trzy kolejne postacie: anioł ze świecą, stojący w drzwiach do kapliczki tyłem do Marii, biskup, który w lewej ręce trzyma pastorał, a w prawej kropidło oraz stojący za nim, zachowany jedynie w dolnej części, kolejny anioł. Dookoła znajduje się ramka z bardzo słabo czytelnym, niewyraźnym i zniekształconym, minuskułowym napisem gotyckim, z którego udało się zidentyfikować jedynie nieliczne litery (... ist.* geben* ..den* ..evich....). Zachowały się dwa całe uszka do mocowania i fragment trzeciego.

Drugi znak z Lastadii (GKPP 1038; nr SAZ: 255/133/004; nr katalogu: 204) jest jednym $z$ lepiej zachowanych tego rodzaju zabytków w Europie, a czytelny odlew umożliwia rozpoznanie detali trudnych do zidentyfikowania na innych egzemplarzach z Einsiedeln. Podobnie jak omawiany poprzednio, został odnaleziony w pobliżu nabrzeża portowego, w kontekście datowanym na XV wiek ${ }^{10}$ (analogie - por. Warncke 1930/1931, s. 158-183, ryc. 12; Köster 1957, s. 1-206, tab. VI, ryc. 34; Wittstock 1982, s. 194, ryc. 3; 1984, s. 16, ryc. 1.1; Andersson 1989, s. 87-90; Lustenberger 2000, s. 265, nr 27; Beuningen, Koldeweij, Kicken 2001, s. 334, nr 1393; Haasis-Berner 2006, s. 237-252). Tym razem dobrze zachowana,

biskupa konsekrującego tę kaplicę. Za biskupem widnieje drugi anioł, który mu pomaga. Plakietka ze Sneek ma napis: + dis.ist.vnser. vrowen. cabell. zeichen. von neisidelen. die wirt. dot. reib. mit engel. Prawie identyczna jest też plakietka z Lubeki z napisem: dis. Ist. vnser. vrawen. cabell. zeichen. von. neisiedelen. die wiet. gott. selb. mit. engell., przechowywana w Sankt-Annen-Museum pod numerem inwentarza 3598 (Warncke 1930/1931, s. 158-183, ryc. 12; Köster 1957; Wittstock 1982, s. 194, ryc. 3; 1984, s. 16, ryc. 1.1; Andersson 1989, s. 87-90; Lustenberger 2000, s. 265, nr 27; Beuningen, Koldeweij, Kicken 2001, s. 334, nr 1393; Haasis-Berner 2006, s. 237-252). Badania przy ul. Szafarnia 12-14 były prowadzone w latach 2008-2009 przez Roberta Krzywdzińskiego.

${ }_{9}$ Parcela nr 35D, wykop 37, warstwa 4205. Badania były prowadzone w 2004 roku przez Marię K. Kocińską.

${ }^{10}$ Ulica Toruńska 12, wykop 3, warstwa 122. Zabytki numizmatyczne z warstwy 122 są w trakcie konserwacji i opracowania. Badania były prowadzone w latach 2007-2008 przez Henryka Dąbrowskiego. 


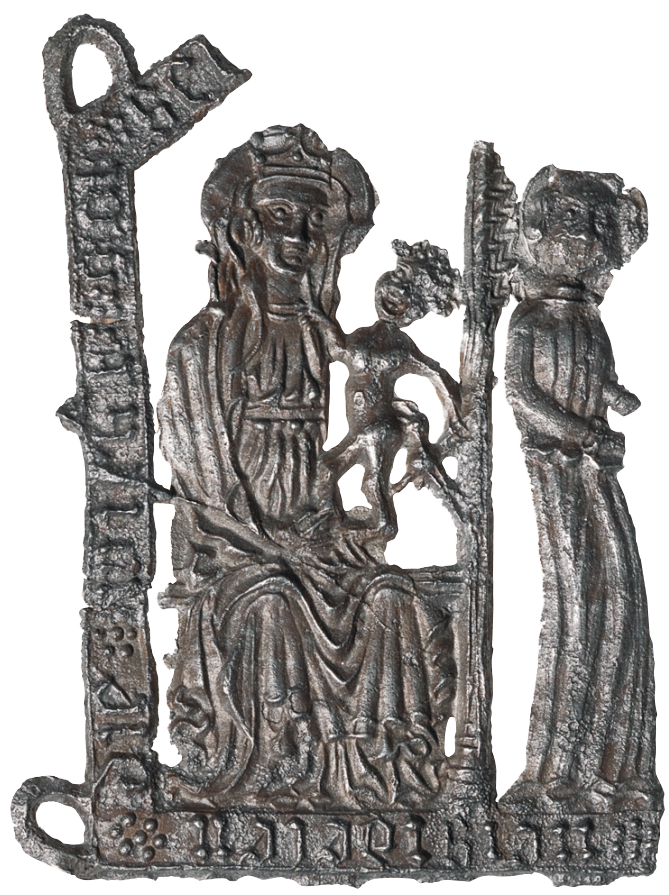

Ryc. 1. Gdańsk, ul. Motławska 1. Fragment plakietki z obrębu podwórka funkcjonującego przed budową pierwszego spichlerza, wniesionego u schyłku średniowiecza (fot. K. Wiącek)

Fig. 1. Gdańsk, 1 Motławska st. Fragment of a plaque from the yard functioning before first granary erecting, at the end of the Middle Ages (photo by K. Wiącek)

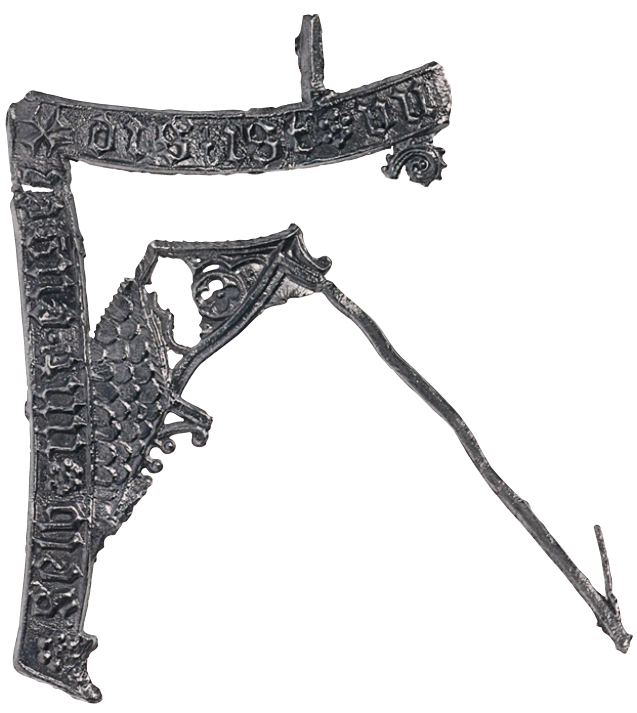

Ryc. 2. Gdańsk, ul. Basztowa 3. Fragment plakietki z kontekstu związanego z kolejną fazą rozbudowy średniowiecznego spichlerza drewnianego (fot. K. Wiącek)

Fig. 2. Gdańsk, 3 Basztowa st. Fragment of a plaque from the context connected with subsequent mediaeval wooden granary development phase (photo by K. Wiącek) 


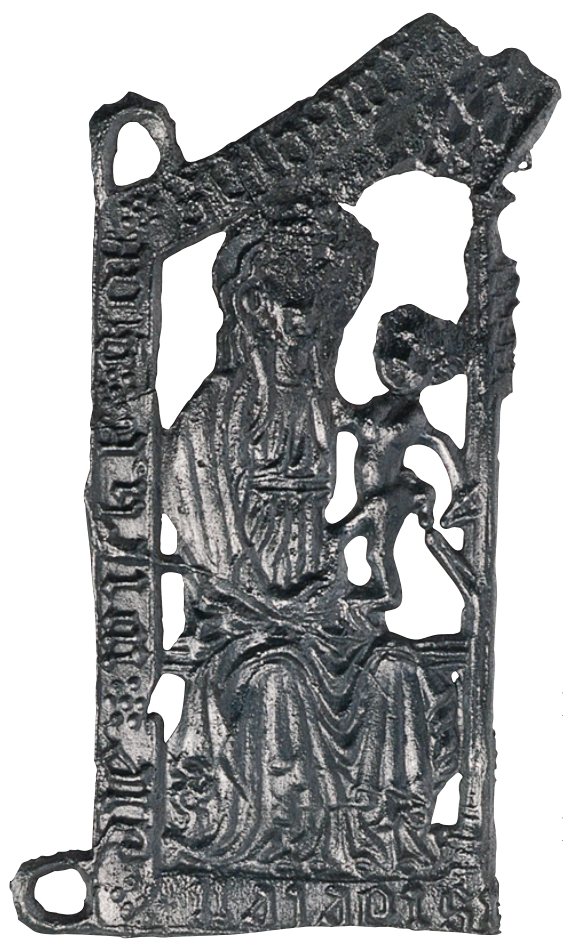

Ryc. 3. Gdańsk, ul. Szafarnia 12-14. Fragment plakietki z nawarstwień niwelacyjnych (fot. K. Wiącek)

Fig. 3. Gdańsk, 12-14 Szafarnia st. Fragment of a plaque from leveling layers (photo by K. Wiącek)

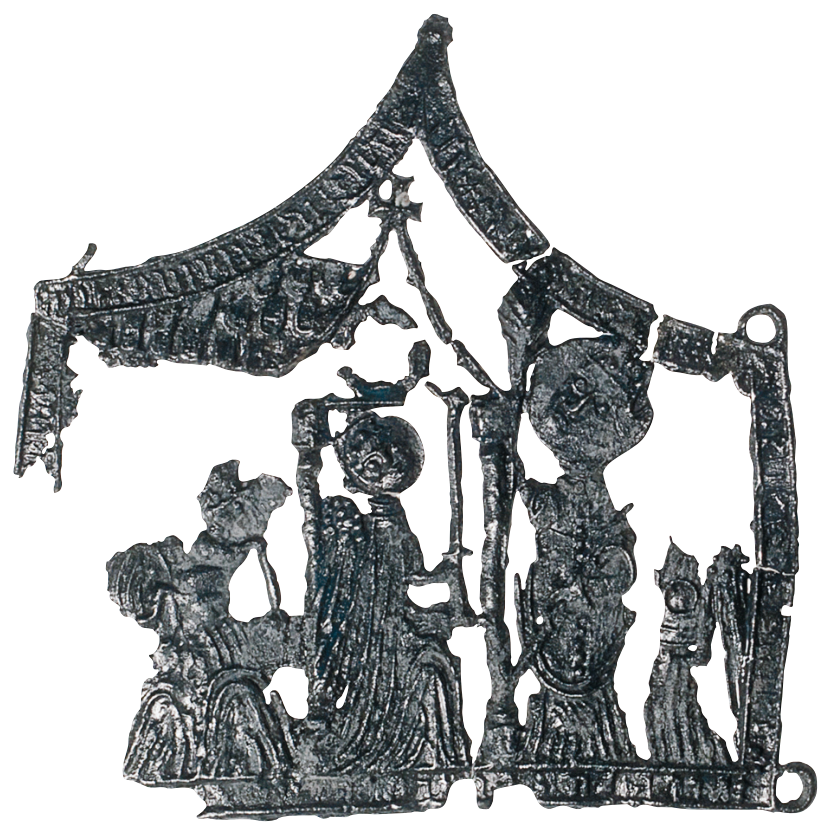

Ryc. 4. Gdańsk, ul. Lastadia. Plakietka z rejonu nabrzeża portowego, z kontekstu datowanego na XV wiek (fot. K. Wiącek)

Fig. 4. Gdańsk, Lastadia st. Plaque from port quay area, from the context dated from $15^{\text {th }}$ century (photo by K. Wiącek) 
wielokątna, ażurowa plakietka o wymiarach 79,1 × 76,4 mm i wadze 19,57 g, zwieńczona jest krzyżem maltańskim. Wewnątrz niej znajduje się znana już niewielka kaplica z daszkiem pokrytym gontem lub dachówką oraz przedstawiona frontalnie Maria z nagim Dzieciątkiem stojącym na jej kolanach. Maria ma koronę na głowie obwiedzionej kolistym nimbem, a w prawej dłoni trzyma jabłko. Po jej lewej stronie, w wejściu do kapliczki znajduje się stojąca postać anioła ze świecą w ręku, przed wejściem do kapliczki stojąca postać biskupa z pastorałem w lewej i kropidłem w prawej ręce, zaś za plecami biskupa drugi anioł z kropielnicą. W otoku, na ramce plakietki znajduje się bardzo wyraźnie odlana inskrypcja pisana gotycką minuskułą, ze słowami rozdzielonymi przez sześciopłatkowe rozetki: dis*ist*vnser*frowen*cabil* ricten* von* neisidelen*die*wirkt*got* selb*mit* engel*. Z czterech uszek dwa dolne zachowane są w całości, a górne fragmentarycznie.

Trzy kolejne plakietki z Einsiedeln zostały odnalezione w obrębie Starego Miasta: przy ulicach Łagiewniki i Sieroca oraz u zbiegu ulic Tartacznej i Panieńskiej. Pierwszą (GKPP 588; nr SAZ: 255/039/007; nr katalogu: 23; ryc. 5) odkryto w kontekście reliktów zabudowy ze schyłku średniowiecza i początków okresu nowożytnego ${ }^{11}$. Choć zachowana jest jedynie w 50\% można dostrzec pewne różnice w przedstawieniu detali postaci w porównaniu do wyżej prezentowanych, natomiast sama kompozycja obrazu jest niezmienna. Tak więc ażurowa plakietka ${ }^{12}$ również przedstawia Madonnę z nagim Dzieciątkiem na rękach, stojącą pod dachem kapliczki. Obok wejścia znajduje się postać anioła trzymającego świecę. $\mathrm{Na}$ zachowanych fragmentach ramki widnieje fragment minuskułowego napisu o treści: *?n? voneinsidel *iendiwihet *got*selbet*mit*eng?.

Plakietka z ulicy Sierocej (GKPP 866; nr SAZ: 255/105/002; nr katalogu: 49), zachowana jedynie w niewielkim ułamku o wymiarach $18,9 \times 29,7 \mathrm{~mm}$, została odkryta w warstwach związanych z reliktami zabudowy mieszkalnej ze schyłku średniowiecza lub z początków okresu nowożytnego ${ }^{13}$. Ten narożny fragment wielokątnej, ażurowej plakietki zawiera przedstawienie głowy Marii w koronie, otoczonej nimbem, nad którą znajduje się część dachu kapliczki, zachowanego jako plastyczny ornament $\mathrm{w}$ formie łuskowato nachodzących na siebie dachówek. Całość otoczona jest delikatną, płaską ramką z niewielkim fragmentem napisu wykonanym minuskułą: ..selb? * ?et* mit.

Zachowana w połowie ażurowa, wielokątna plakietka z ulicy Tartacznej (GKPP 885; nr SAZ: 255/004/004; nr katalogu: 13; ryc. 6), została znaleziona w zasypie niewielkiego kanału wraz z monetami i liczmanami datowanymi od XV do XVIII wieku ${ }^{14}$. Znak ten, o zachowanych wymiarach $39,9 \times 50,7 \mathrm{~mm}$, także przedstawia

${ }^{11}$ Sektor 29, warstwa 2427. Badania były prowadzone w 2006 roku przez Katarzynę Kaczyńską.

12 Zachowane wymiary to $38,3 \times 51,0 \mathrm{~mm}$.

${ }_{13}$ Ulica Sieroca 4, wykop 1, warstwa 199. Badania były prowadzonew 2006 roku przez Agnieszkę Rutę.

${ }_{14}$ Monety i liczmany według B. Paszkiewicza (2005): Prusy - fenig brakteatowy Krzyż grecki III, lata 1416-1460; Norymberga - liczman anonimowy, hybryda typu paryskiego i burgundzkiego, schyłek XV wieku; Norymberga - liczman anonimowy, lata około 1490-1550; Francja - Henryk VI 
Marię z nagim Dzieciątkiem, siedzącym na jej lewym ramieniu, znajdującą się pod daszkiem z plastycznym ornamentem w formie łuskowato nachodzących na siebie dachówek. Maria ma koronę na głowie obwiedzionej kolistym nimbem. W wejściu do kapliczki, tyłem do Madonny, widnieje stojąca postać anioła ze świecą w ręku. Całość otoczona jest delikatną, płaską ramką z zachowanym we fragmencie minuskułowym napisem o treści: ?dalan...*wichet ${ }^{*}$ got ${ }^{*}$ selb $^{*}$ et ${ }^{*}$ mit*.

Wreszcie ostatni i najlepiej zachowany znak pielgrzymi (GKPP 1027; nr SAZ: 255/129/004; nr katalogu: 905; ryc. 7) został odnaleziony na Głównym Mieście, nieopodal kościoła Mariackiego, przy ulicy Kleszej nr 6, wśród reliktów zabudowy mieszkalnej datowanej na XV wiek $^{15}$. Ma on wymiary $74,4 \times 79,2 \mathrm{~mm}$ oraz wagę 23,87 g. Ten wspaniale zachowany zabytek prezentuje wielkie mistrzostwo wykonania formy i precyzję odlewu. Dobrze już nam znane przedstawienie to Maria z nagim Dzieciątkiem, umieszczona pod dachem kapliczki, obok której stoi anioł ze świecą. Przed wejściem do kapliczki znajduje się postać biskupa trzymającego kropidło i pastorał, za nim zaś anioł z kropielnicą. W otoku, na ramce plakietki, widnieje inskrypcja pisana gotycką minuskułą, ze słowami rozdzielonymi przez sześciopłatkowe rozetki, o treści: dis*ist*vinser*froven*kapel*......*on*neisidell en*die*got*selb*wirht*mit*eng..*.

\section{Treść przedstawień}

Obecnie Einsiedeln to najbardziej popularne sanktuarium na terenie Szwajcarii, odwiedzane przez około 500000 pielgrzymów rocznie. Miejsce to zasłynęło najpierw w IX wieku za sprawą eremity Meinarda, który zbudował tu niewielką kaplicę dla słynącej z cudów figurki Marii Panny. Po kilku latach został on zamordowany, a następnie ogłoszony świętym. W miejscu jego pustelni zbudowano Kaplicę Łaski, która następnie stała się częścią wzniesionego tu w 934 roku klasztoru benedyktynów. Wydarzenie to upamiętniają między innymi inne znaki pielgrzymie przedstawiające kaźń eremity, jak dotąd, nie zostały one jednak odnalezione w Polsce. Prezentowane w niniejszym artykule plakietki upamiętniają okoliczności związane z konsekracją klasztoru Benedyktynów w Einsiedeln przez biskupa Konrada z Konstancy. W noc z 13 na 14 września 948 roku, poprzedzającą konsekrację tej kaplicy miał ją wyświęcić sam Chrystus wraz z towarzyszącym mu aniołem, a biskup po przybyciu następnego dnia do świątyni usłyszał następujące słowa: „Odstąp bracie - bóg sam wyświęcił kaplicę”. W literaturze przedmiotu opisane wyżej znaki znane są jako „typ święcenia anioła” (niem. Engelweihe) i wielokrotnie występują w postaci odlewów na dzwonach kościelnych. Natomiast znacznie mniej liczne są znaleziska oryginalnych plakietek, a dobrze zachowane

angielski, liczman, mennica w Paryżu(?), lata około 1418-1437; Norymberga - liczman anonimowy, typ B. Burgrabia norymberski, 2. połowa XV wieku; Norymberga - Johann Jacob Dietzel (działał w latach 1711-1748), liczman.

15 Warstwa 313. Badania były prowadzone w latach 2008-2008 przez Krzysztofa Dyrdę. 


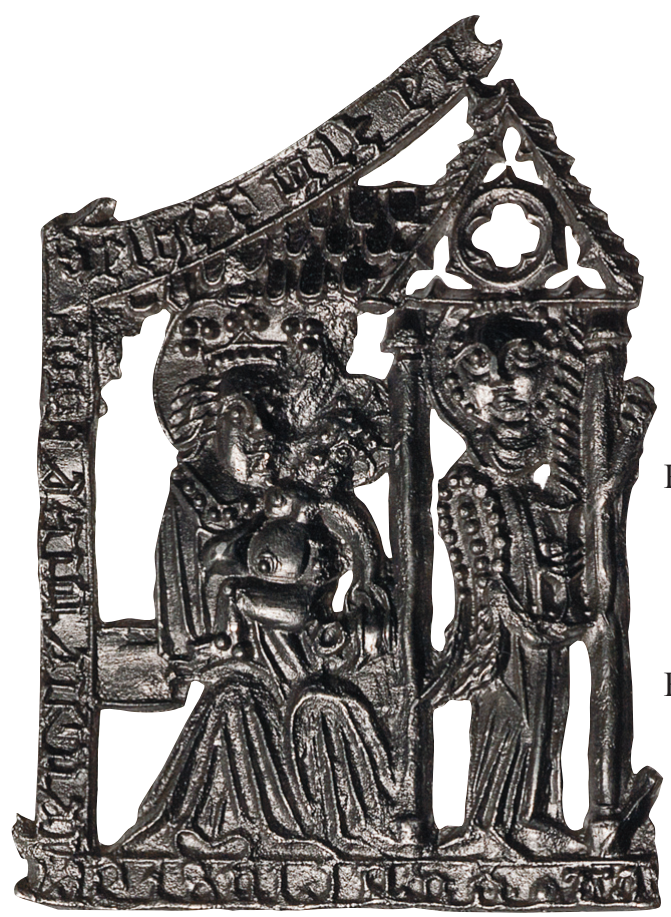

Ryc. 5. Gdańsk, ul. Łagiewniki. Fragment plakietki z kontekstu reliktów zabudowy ze schyłku okresu średniowiecznego i początku okresu nowożytnego (fot. K. Wiącek)

Fig. 5. Gdańsk, Łagiewniki st. Fragment of a plaque from the context of architectonic relics originating from the end of the Middle Ages and beginning of modern period (photo by K. Wiącek)

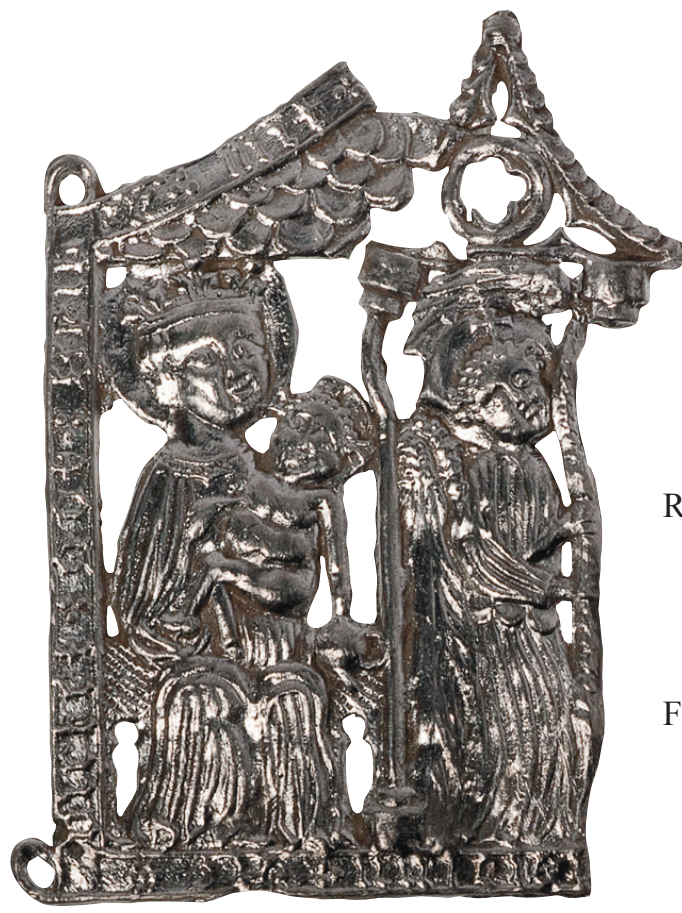

Ryc. 6. Gdańsk, ul. Tartaczna. Fragment plakietki z zasypiska kanału, znaleziony wraz z monetami $\mathrm{i}$ liczmanami datowanymi od XV do XVIII wieku (fot. K. Wiącek)

Fig. 6. Gdańsk, Tartaczna st. Fragment of a plaque from the canal backfill, excavated together with coins and tallyman dated from $15^{\text {th }}$ to $18^{\text {th }}$ century (photo by K. Wiącek) 


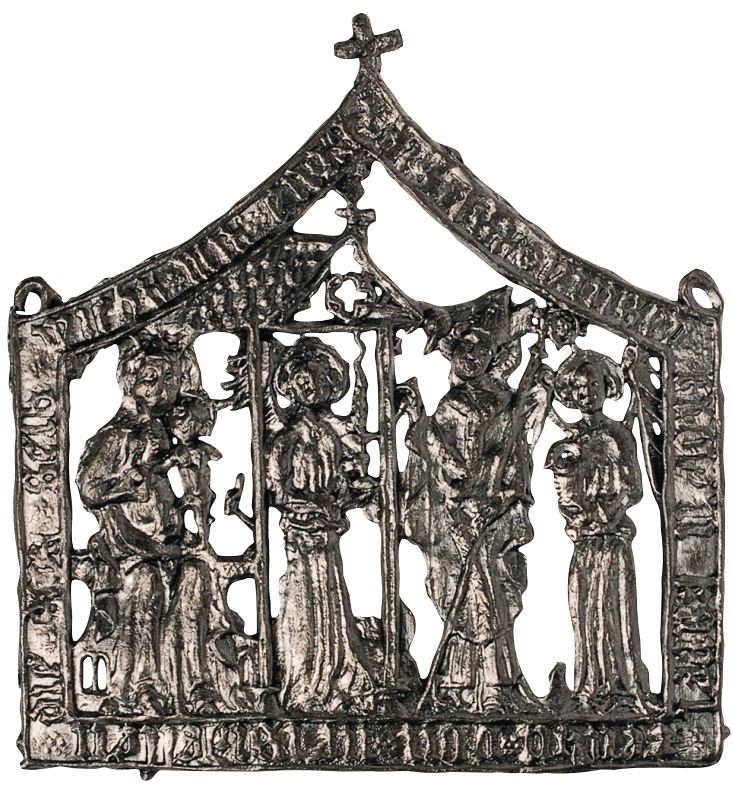

Ryc. 7. Gdańsk, ul. Klesza 6. Znak z Einsiedeln znaleziony w kontekście reliktów zabudowy mieszkalnej datowanej na XV wiek (fot. K. Wiącek)

Fig. 7. Gdańsk, 6 Klesza st. Sign from Einsiedeln excavated in the context of dwelling house relics dated from $15^{\text {th }}$ century (photo by K. Wiącek)

można policzyć na palcach jednej ręki. Jak już wspomniano, znaki różnią się między sobą detalami (np. stojące lub siedzące Dzieciątko, dłuższy lub krótszy napis), wynikającymi z faktu, że przy ich masowej produkcji zachowywano ten sam schemat kompozycyjny, choć wykonywano je przy użyciu różnych form odlewniczych ${ }^{16}$. W końcu XIV wieku Einsiedeln było jednym z ważniejszych ośrodków pielgrzymkowych, gdzie pierwszy cud zanotowano w roku 1388, a o popularności tego miejsca może świadczyć liczba sprzedawanych tu znaków pielgrzymich, których w 1466 roku w ciągu dwóch tygodni sprzedano nie mniej niż 130 000, po dwa fenigi za sztukę (Köster 1972, s. 147). Co ciekawe, w Einsiedeln powoływano specjalne rady, które organizowały i kontrolowały handel pamiątkami. Głównym magnesem dla pielgrzymów była cudowna, słynąca cudami figura Czarnej Madonny. Do dziś 14 września każdego roku obchodzone jest Święto Cudownej Konsekracji Kościoła, celebrowane procesją z pochodniami.

\section{Występowanie, kontekst i datowanie}

Jak już wspomniano, większość plakietek z Einsiedeln znamy z odlewów na dzwonach datowanych przeważnie na 1. połowę XV wieku. Oryginalne znaki znaleziono na terenie Niemiec i Austrii jedynie w kilku miejscach, przy czym najlepiej spośród nich zachowane są dwa: z Lubeki, wyłowiony przypadkowo z rzeki Trawy

${ }^{16}$ Wybitny badacz znaków pielgrzymich - Kurt Köster - wyróżnił dwa typy tych plakietek: typ A - z dłuższą inskrypcją, na ogół brzmiącą: dis. ist. vnser/frowen. cabell/[zaich]en. von [neisidelen] die. wiett. got/selb. mit. Engel oraz typ B - z krótszą inskrypcją, brzmiącą: dis ist/unser frowen/ zaichen in/dem winstren/wald. 
i datowany na XV wiek, oraz z Sankt Gallen. Kilka dobrze zachowanych tego rodzaju plakietek znamy z Nieuwlande i Sneek w Holandii (1. połowa XV wieku), a także Gamla-Lödöse w Szwecji, fragmenty zaś z Wienhausen i Amsterdamu.

Plakietki z Einsiedeln znalezione w Gdańsku pochodzą z różnych części miasta (Wyspa Spichrzów, Stare i Główne Miasto, Lastadia, ulica Szafarnia). Mimo ich pozornie dużego rozrzutu znaki z ulicy Szafarnia (1), Wyspy Spichrzów (2) oraz Lastadii (2) usytuowane są w samym sercu średniowiecznego portu gdańskiego, zaś ze Starego Miasta raczej na jego obrzeżach, z czego dwa znaleziono na terenach między zamkiem krzyżackim a północno-wschodnimi peryferiami tej dzielnicy. Jak wyżej wspomniano znaleziska wydobyto z różnych kontekstów - na Wyspie Spichrzów z obrębu podwórka i drewnianego spichlerza (brak zabudowy mieszkalnej), w przypadku Lastadii - z rejon portu Przy Starej Motławie oraz miejsca naprawy i budowy statków (brak zabudowy mieszkalnej), z ulicy Szafarnia - z rejonu portu przy kanale Nowej Motławy. Na Starym Mieście były to relikty zabudowy mieszkalnej ze schyłku średniowiecza i początków okresu nowożytnego oraz wypełnisko niewielkiego kanału uchodzącego do rzeki Raduni, na Głównym Mieście zaś pozostałości zabudowy mieszkalnej z XV wieku. Niestety, żaden z kontekstów, znalezionych w Gdańsku, znaków pielgrzymich z Einsiedeln nie dostarczył informacji niezbędnych do bardziej precyzyjnego datowania, niemniej wszystkie mieszczą się w przedziale chronologicznym przyjętym dla nich w literaturze - tj. od schyłku XIV po XV wiek.

\section{Gdańsk i Einsiedeln}

Dzięki pracom historyków francuskich i holenderskich znamy cele pielgrzymek sądowych (pokutnych), jakimi w średniowieczu karano winowajców w kilku miastach flandryjskich (Cauwenbergh 1922; Viaenne 1937; Koldeweij 2006, s. 222). W Holandii było ich 28, we Francji 84, w krajach niemieckich 23, w Anglii, Szkocji i Irlandii 14, we Włoszech 25, w Hiszpanii 5, w Szwajcarii 3, na Bliskim Wschodzie 7 oraz - co nas najbardziej interesuje - w Europie Centralnej 3 i 5 w Europie Północnej. W dokumentach z Brugii i Gandawy, określających taryfy sądowe z XV wieku, zachowały się ceny za wykupienie się od karnej pielgrzymki do Gdańska i Gniezna (Witkowska 1995, s. 16). W oparciu o dokumenty z lat 1320-1521, zachowane w trybunale paryskim, który zatwierdzał kary wydane przez sądy niższych instancji, ustalono, że w 17 wyrokach nałożono 29 pielgrzymek do różnych miejsc, w tym także do Kolonii, Einsiedeln, Rzymu oraz Santiago de Compostela. Kiedy w roku 1384 pielgrzymowali do Akwizgranu Gdańszczanie - Dorota z Mątów i jej małżonek Adalbert (Kwiatkowski 1990, s. 98), udali się również do sławnego już wówczas Einsiedeln. Dorota, u której dojrzewała decyzja o porzuceniu rodziny i życiu w pustelni, pragnęła także odwiedzić sanktuarium zwane Vinstervald oraz przyjrzeć się życiu beginek, które 
osiedliły się w klasztorze Alpegg, w dolinie rzeki Au. W Akwizgranie i Einsiedeln działały stowarzyszenia Ruchu Przyjaciół Bożych, z którymi Dorota zetknęła się już wcześniej w Gdańsku (Kwiatkowski 1990, s. 82), a ideologia tego ruchu w znaczącym stopniu miała wpływ na jej życie duchowe.

Cennym źródłem do poznania dziejów średniowiecznych pielgrzymek są zapisy testamentowe ${ }^{17}$. W pobliskim Elblągu zachowało się 30 ze 145 znanych testamentów, które wspominają odbycie pielgrzymki w intencji testatora. Łącznie źródła te wymieniając dziewięć celów pielgrzymek mieszczan elbląskich - tj. Rzym, Wilsnack, Akwizgran, Santiago de Compostela, Sternberg ${ }^{18}$, Vadstena, Rosenkoll, Einsiedeln oraz Koszalin (Góra Chełmska), z czego jedynie trzy ostatnie sanktuaria, do których pielgrzymowano po jednym razie oraz wymieniony dziewięciokrotnie Akwizgran, związane były z kultem Najświętszej Marii Panny ${ }^{19}$.

Ciekawe jest porównanie $\mathrm{z}$ takimi samymi materiałami z Lubeki i Stralsundu. Według pozostawionych zapisów testamentowych mieszkańcy Lubeki najczęściej pielgrzymowali do Akwizgranu i Wilsnack (odpowiednio 128 i 1224 razy), do Rzymu i Einsiedeln (odpowiednio 76 i 72 razy) oraz do Thann (Francja) i Santiago de Compostela (odpowiednio 111 i 46 razy). Z kolei celem wędrówek mieszczan ze Stralsundu były najczęściej Rzym i Wilsnack (odpowiedni 68 i 85 razy), Akwizgran, Einsiedeln i Golme, tj. Góra Chełmska ${ }^{20}$ (odpowiednio 53, 51 i 38 razy), znacznie rzadziej Santiago, bo tylko pięć razy oraz Vadstena zapisana jedynie w jednym przypadku (Bettin, Volksdorf 2002, s. 224²1). Mamy podstawy, aby przypuszczać, że wiele gromadnych pielgrzymek przynajmniej w części swojej trasy wykorzystywało drogi morskie, a statki przewożące pielgrzymów, w szczególności zmierzających do Santiago de Compostela, wyruszały między innymi z Gdańska (Bettin, Volksdorf 2002, s. 214-215; por. też Samsonowicz 2002, s. $128^{22}$ ). W testamencie elblążanina Piotra Rewmelandta opisana jest trasa

${ }^{17}$ Interesujące informacje na temat geografii pielgrzymek mieszczan elbląskich opublikował ostatnio Rafał Kubicki (2010, s. 179-188; por. też 2006, s. 199-208). Podobne opracowanie znamy również dla Stralsundu (Bettin, Volksdorf 2002, s. 211-233). W tej publikacji znajdziemy także informacje dotyczące dokonanych w Lubece zapisów testamentowych dotyczących pielgrzymek.

${ }^{18}$ Sternberg - miasto położone na obszarze Meklemburgii, ważny ośrodek kultu Bożego Ciała, który nabrał znaczenia dopiero u schyłku XV wieku.

19 Daty pielgrzymek do Akwizgranu, podane przez R. Kubickiego to lata 1425, 1447, 1453 , 1454, 1457, 1465, 1472, 1481, 1515, do Rosenkoll- 1472 rok, Einsiedeln - 1472 rok i Góry Chełmskiej - 1472 rok (Kubicki 2010, s. 181).

${ }^{20}$ Kaplica pod wezwaniem Najświętszej Marii Panny w Górze Chełmskiej, położona obecnie na terenie Koszalina, znana jest ze źródeł także pod nazwą Golmberg, Gollen, Gholme lub Golme.

${ }^{21}$ Znajdziemy tu również dane o pielgrzymkach mieszkańców Stralsundu i Lubeki (por. też Kubicki 2010, s. 138, tab. 2 na s. 183 -zestawienie pielgrzymek wymienionych w testamentach mieszczan Elbląga, Stralsundu i Lubeki).

${ }^{22}$ Autor ten podaje, że podróż morska z Gdańska do Composteli trwała wówczas 15 dni, a podróż lądowa około 70 dni. 
wędrówki do Rzymu poprzez Górę Chełmską (obecnie w granicach Koszalina), Wilsnack, Akwizgran i Einsiedeln (Kubicki 2010, s. 184, mapa na s. 187).

Być może to właśnie znaczenie Gdańska na transportowych szlakach Europy stanowi, obok kilku innych powodów, o tak wielkiej liczbie znajdowanych tu średniowiecznych pamiątek pielgrzymich z zachodnioeuropejskich sanktuariów, w tym także tych z Einsiedeln.

\section{Literatura}

Andersson L.

1989 Pilgrimsmärken och vallfart. Medeltida pilgrimskultur i Skandinavien, Lund Studies in Medieval Archaeology, t. 7, Lund.

Bettin H., Volksdorf D.

2002 Pielgrzymki w testamentach mieszczan stralsundzkich jako zwierciadto mieszczańskiej religijności, [w:] Kult św. Jakuba Większego apostoła w Europie Środkowo-Wschodniej, red. R. Knapiński, Lublin, s. 211-233.

Beuningen van H. J. E., Koldeweij A. M.

1993 Heilig en Profaan. 1000 Laatmiddeleeuwse Insignes uit de collectie H. J. E. van Beuningen, Rotterdam Papers 8, Cothen.

Beuningen van H. J. E., Koldeweij A. M., Kicken D.

2001 Heilig en Profaan. 1200 Laatmiddeleeuwse Insignes uit openbare en particular collecties, Rotterdam Papers 12, Cothen.

Böck H.

1991 Einsiedeln. Das Kloster und seine Geschichte, Zürich.

Cauwenbergh E.

1922 Les pèlerinages expiatoires et judiciaires dans le droit communal de la Belgique au Moyen âge, Receuil de travaux publiés par les membres des Conférences d'Histoire et de Philologie 48, Leuven.

Haasis-Berner A.

2006 Pilgerzeichen zwischen Main und Alpen, [w:] Wallfahrten in der europäischen Kultur. Pilgrimage in European Culture, red. D. Doležal, H. Kühne, Europäiche Wallfahrtsstudien, t. 1, Frankfurt am Main, s. 237-252.

Heeringen van R. M., Koldeweij J., Gaalman A. A. G.

1987 Heiligen uit de modder. In Zeeland gevonden pelgrimstekens, Utrecht-Zutphen.

Koldeweij A. M.

1999 Lifting the Veil on Pilgrim Badges, [w:] Pilgrimage explored, red. J. Stopford, York, s. 161-188.

2006 Foi et bonne fortune, Arnhem.

Köster K.

1957 Meister Tilman von Hachenburg. Studien zum Werk eines mittelrheinischen Glockengießers des fünfzehnten Jahrhunderts. Mit besonderer Berücksichtigung der als Glockenzier verwendeten mittelalterlichen Pilge - und Wall- 
fahrtszeichen, Jahrbuch der Hessischen Kirchengeschichtlichen Vereinigung, t. 8, s. 1-206.

1972 Mittelalterliche Pilgerzeichen und Wallfahrtsdevotionalien, [w:] Rhein und Maas. Kunst und Kultur 800-1400 (Ausstellungskatalog Köln 1972), red. A. Legner, Köln.

Kubicki R.

2006 Testamenty elblaskie z XIV-początków XVI w., Rocznik Elbląski, t. 20, s. 199-208.

2010 Pielgrzymki w testamentach mieszczan elblaskich w XV-poczatkach XVI w., [w:] Z dziejów średniowiecza. Pamięci profesora Jana Powierskiego (1940-1999), red. W. Długokęcki, Gdańsk, s. 179-188.

Kwiatkowski S.

1990 Klimat religijny $w$ diecezji pomezańskiej u schyłku XIV $i$ w pierwszych dziesięcioleciach $X V$ wieku, Roczniki Towarzystwa Naukowego w Toruniu, R. 84, z. 1, Toruń.

Lustenberger $\mathrm{O}$.

2000 Bild und Abbild. Einsiedler Pilgerzeichen, Einsiedler (Gnaden)-Kapellen, Einsiedler Gnadenbilder. Ein Forschungsbericht, Sankt Meginrat.

Paner A., Paner H.

1998 Gdańszczanie na pielgrzymkowych szlakach XIV i XV wieku, [w:] Gdańsk średniowieczny w świetle najnowszych badań archeologicznych $i$ historycznych, red. H. Paner, Gdańsk, s. 167-183.

Paner H.

1993a Wyspa Spichrzów w Gdańsku, Pomorania Antiqua, t. 15, s. 155-188.

1993b Badania ratownicze na Starym Mieście w Gdańsku w 1990 roku, Gdańsk stanowisko 2, [w:] Sprawozdania Gdańskiego Towarzystwa Naukowego, nr 18 , s. 53-56.

1993c The Industrial Heritage of Granary Island, [w:] Preservation of the Industrial Heritage - Gdańsk outlook, International Seminar - European Workshop, Gdańsk, s. 125-131.

1997a The Archaeology of Gdańsk [w:] Lübecker Kolloquim zur Stadtarchäologie im Hanseraum I: Stand, Aufgaben und Perspektiven, t. 1, red. M. Gläser, Lübeck, s. 277-291.

1997b Z Zadań archeologicznych Gdańska. Historia i aktualności, Rocznik Gdański, 57/1, s. 7-35.

2009 Archeologia Gdańska w latach 1988-2005, [w:] Archeologia Gdańska, t. 1, red. H. Paner, Gdańsk, s. 11-88.

Paszkiewicz B.,

2005 Katalog zabytków numizmatycznych z badań archeologicznych przy ul. Tartacznej 2 (SAZ 255/04/04), część 1, maszynopis w archiwum Muzeum Archeologicznego w Gdańsku, Gdańsk.

w druku Materiały numizmatyczne i metrologiczne ze stanowiska Szafarnia w Gdańsku (SAZ 255/100/05), [w:] Archeologia Gdańska, t. 5, red. H. Paner, Gdańsk. 
Plötz R.

$1981 \quad$ Kirchliche Kunst des Mittelalters und der Reformationzeit, Lübeck. Samsonowicz H.

2002 Kult św. Jakuba i szlaki Jakubowe w Polsce, [w:] Kult św. Jakuba Większego Spencer B. apostoła w Europie Środkowo-Wschodniej, red. R. Knapiński, Lublin.

1968 Medieval pilgrim badges. Some general observations illustrated mainly from English sources, [w:] Rotterdam Papers. A contribution to medieval archaeology, red. J. G. N. Renaud, Rotterdam, s. 137-153.

1998 Pilgrim Souvenirs and Secular Badges, Medieval Finds from Excavations in London 7, London.

Viaenne A.

1937 Strafbedevaarten in de rechtspraak van het O. L. Vrouvekapittel te Kortrijk, Annales de la Société d'Émulation de Bruges 80, Bruges.

Warncke J.

1930/1931 Mittelalterliche Pilgerzeichen aus Lübeck und Lauenburg, Nordelbingen 8, s. $158-183$.

Witkowska A.

1995 Peregrinatio religiosa w średniowiecznej Europie, [w:] Peregrinationes. Pielgrzymki w kulturze średniowiecznej Europy, red. H. Manikowska, H. Zaremska, Warszawa, s. 9-16.

Wittstock J.

1982 Pilgerzeichen und andere Wallfahrtsdevotionalien in Norddeutschland, [w:] Aus dem Alltag der mittelalterlichen Stadt, Hefte des Focke-Museums 62, red. R. Pohl-Weber, Bremen, s. 193-200.

1984 Pilgerzeichen in Lübeck. Alte und Neue Funde, Lübecker Schriften zur Archäologie und Kunstgeschichte 8, s. 15-21.

\section{MEDIEVAL PILGRIM SOUVENIRS FROM EINSIEDELN IN THE COLLECTION OF THE GDAŃSK ARCHAEOLOGICAL MUSEUM}

Summary

There are nine pilgrim signs from Einsiedeln (Switzerland) registered in the Collection of the Medieval Pilgrimage Souvenirs created by the author of this article among other collections in the Gdańsk Archaeological Museum. These artefacts were discovered during rescue excavations carried out systematically in Gdańsk since 1988 (Paner 1988, s. 11-88). Two of them come from the Granary Island, one of Long's Gardens, two from Lastadia district, three from the Old Town and one of the Main Town. The badges presented in this paper commemorate the events and circumstances related to the consecration of the Benedictine monastery in Einsiedeln by Bishop Conrad of Constanta. On the night of from $13^{\text {th }}$ to $14^{\text {th }}$, in 948 , followed by the consecration of the chapel, Jesus Christ in person had consecrate the chapel accompanied by an angel, and the bishop after the arrival in the next day to the temple heard the words: „Do not do that - Brother - God 
himself consecrated the chapel!" In the literature, this type of signs is known as a „type of angel blessing" (Engelweihe) and often occurs in the form of castings on the church bells dated to the $15^{\text {th }}$ century.

At the end of the fourteenth century Einsiedeln was one of the most important pilgrimage centre in medieval Europe, where the first miracle observed in 1388. The popularity of this place can be evidenced by the number of pilgrim badges not less than 130000 , sold here in the year 1466 during the two weeks. Despite the seemingly large spread of these discoveries the signs found in Szafarnia (1), Granary Island (2) and Lastadia (2) are located in the major centre of the medieval port of Gdańsk. As for the contexts of finds they are the following: Granary Island: the yard and wooden granary (no residential development); Lastadia - the area of the port of the Old Motława River and the place of repair and ship construction (no residential development); Szafarnia: the new port area next to the canal of the New Motława River; Old Town: the relics of residential buildings from the late Middle Ages and early modern period, filling a small channel escaping to the river channel Radunia; Main City: relics of a residential building of the fifteenth century. Many residents of Gdańsk and Pomerania made pilgrimages to Einsiedeln but also many pilgrims were coming from other countries to Gdańsk, looking for convenient transport connections here. Perhaps the particular importance of Gdańsk as an important point on the medieval pilgrim routes of Europe, is next between several other reasons for such a large number of medieval pilgrim souvenirs from West-European Sanctuaries found here - including those from Einsiedeln. 
